\title{
MUHASABAH BANK SYARIAH DALAM PENERAPAN PRINSIP BAGI HASIL
}

\author{
Rita Yuliana \\ Universitas Trunojoyo Madura, PO BOX 2 Telang Madura \\ Email: yuliana_rita@yahoo.co.id
}

\begin{abstract}
Abstrak: Muhasabah Bank Syariah dalam Penerapan Prinsip Bagi Hasil. Bank syariah telah tumbuh dengan cepat. Namun demikian, perkembangan tersebut rupanya tidak diiringi dengan kepatuhan pada prinsip syariah yaitu penerapan prinsip bagi hasil. Padahal, prinsip bagi hasil merupakan salah satu pembeda utama antara bank syariah dan bank konvensional. Untuk itu, perlu berbagai upaya untuk mengembalikan bank syariah ke "jalur yang benar" supaya apa yang sudah dicapai oleh bank syariah tidak semata berdimensi duniawi, secara ukhrawi. Upaya tersebut dipilah menjadi dua, yaitu dari internal dan dari eksternal yang meliputi pemerintah, masyarakat, akademisi, dan alim ulama.
\end{abstract}

Abstract: Muhasabah Shariah Bank in the Implementation of Profit Sharing. Bank shariah has been growing rapidly. However, the growth is not in line with the pursuance to sharia principle, namely profit-loss sharing. This principle distincts shariah bank with the conventional one. Therefore, it is important to redirect shariah bank "back on the right track" in order to fulfil its mission both in the material world, and hereafter. This effort must be supported internally by bank sharia as well as externally by government, society, academics, and moslem scholar.

Kata kunci: bank syariah, bagi hasil, prinsip syariah

Di balik pesatnya perkembangan bank syariah di Indonesia, terdapat fenomena pengabaian prinsip operasionalnya, yaitu bagi hasil. Hal tersebut ditunjukkan dari minimnya implementasi produk berbasis bagi hasil yaitu mudharabah dan musyarakah. Justru produk murabahah yang mendominasi operasional bank syariah. Hal ini menarik untuk ditelaah mengingat pertumbuhan perbankan syariah, khususnya di Indonesia sangat pesat (pertumbuhan asetnya mencapai 44\%). Jangan sampai berita menggembirakan tersebut ternodai oleh praktik yang bisa mencoreng nama baik perbankan syariah di Indonesia yang dikenal sebagai Negara muslim terbesar sedunia.

Fenomena pengabaian prinsip bagi hasil tersebut ditunjukkan dari fakta kecilnya porsi produk pembiayaan berbasis bagi hasil yaitu mudharabah dan musyara- kah yang secara umum porsinya tidak lebih dari 15\% (Bank Indonesia 2011, 2012). Sebaliknya, bank syariah justru mempraktikkan akad jual-beli yang bukan merupakan akad berbasis bagi hasil. Bukti menunjukkan besarnya porsi pembiayaan murabahah per Oktober 2011 yang tercatat sebesar $42,42 \%$ dan pada Oktober 2012 meningkat menjadi 59,71\%.

Rupanya fenomena keengganan bank syariah untuk mengimplementasikan produk berbasis bagi hasil tidak hanya berlaku di Indonesia. Fenomena serupa juga mewabah di dunia. Fakta tersebut didukung secara empiris oleh penelitian Timberg (2003) dan Vinnicombe (2010).

Menarik untuk ditelaah mengapa bank syariah terkesan enggan mengimplementasikan produk berbasis bagi hasil. Rupanya bank syariah menilai kontribusi produk berbasis bagi hasil

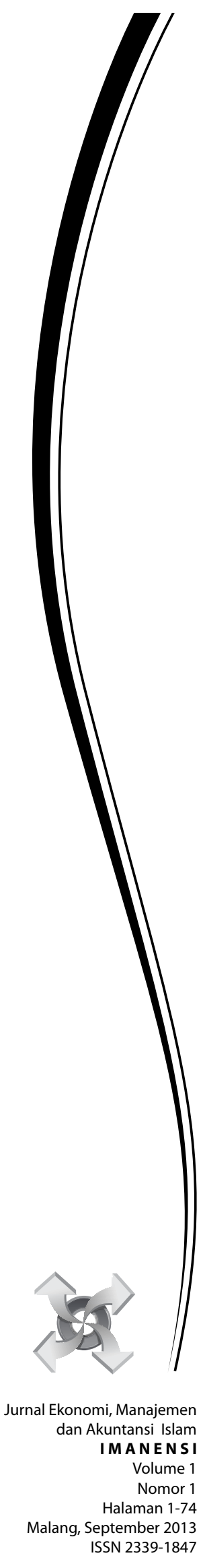


dalam menghasilkan pendapatan lebih rendah jika dibandingkan dengan produk murabahah. Hal ini disebabkan produk berbasis bagi hasil mengandalkan kinerja nasabah dalam mengelola dana yang diinvestasikan oleh bank syariah sebagai dasar pendapatan bank syariah. Terlebih lagi, bank syariah juga menanggung risiko kerugian yang mungkin timbul.

Selain itu, karena laba/rugi dari usaha nasabah yang menjadi dasar pembagian bagi hasil, maka ada potensi nasabah kurang jujur dalam melaporkan kinerja tersebut. Bank juga menanggung risiko yang timbul dari pembiayaan berbasis bagi hasil berupa side streaming, yaitu nasabah menggunakan dana itu bukan seperti yang disebut dalam kontrak. Risiko lainnya adalah kemungkinan kelalaian dan kesalahan yang disengaja. Risiko-risiko itulah yang menyebabkan bank syariah berat untuk melepas dananya untuk diinvestasikan dalam akad berbasis bagi hasil.

Segala risiko itulah yang menjadikan bank syariah berpraktik kurang sesuai dengan kaidah dasarnya. Hal ini sangat disayangkan mengingat harapan besar yang disandarkan pada bank syariah untuk bisa mendorong perekonomian yang kuat dan berdampak pada pembangunan. Harapan itu bisa terwujud melalui ketersediaan pembiayaan berbasis bagi hasil dalam jumlah yang memadai (Iqbal 1998:49).

Pembiayaan berbasis bagi hasil diklaim bisa mendorong perekonomian yang kuat. Alasannya adalah bahwa pada akad berbasis bagi hasil, terjadi aktivitis ekonomi riil yang mengedapankan prinsip keadilan dan kejujuran (Hasan 2003:179). Pihak-pihak yang terlibat pada akad ini mempunyai kewajiban dan hak yang sepadan dengan kinerjanya. Kinerja tersebut yang menjadi tolok ukur penentuan bagi hasil yang dalam proses penentuannya diperlukan kejujuran.

Namun demikian, kejujuran yang masih kurang rupanya menjadi kendala dalam implementasi akad berbasis bagi hasil. Terkait dengan itu, perlu upaya-upaya untuk mengedepankan dan mengkondisikan situasi supaya kejujuran dapat berlaku sehingga prinsip bagi hasil dapat diimplementasikan dengan baik.

Di sisi lain, fakta menunjukkan bahwa bank syariah menyukai produk murabahah. Adanya dominasi produk murabahah pada bank syariah menarik untuk dicermati.
Akad murabahah merupakan akad jual beli, bukan akad kerjasama yang menggunakan prinsip bagi hasil. Berbeda dengan akad bagi hasil, pada akad murabahah bank syariah mendapatkan pendapatan yang bersifat tetap/pasti berupa marjin/keuntungan. Bank syariah tidak menghadapi risiko yang terlalu besar dalam mengelola dananya ketika menggunakan akad tersebut.

Meskipun demikian, dominasi produk murabahah jelas menyalahi prinsip bagi hasil yang menjadi dasar operasional bank syariah. Keberadaan prinsip bagi hasil pada bank syariah menjadi pembeda antara bank syariah dengan bank konvesional (Chong dan Liu 2009; Khan 2010). Prinsip bagi hasil inilah yang menghapus sistem bunga. Jadi, karena bagi hasil menjadi prinsip dasar operasional bank syariah, maka produk yang berbasis bagi hasil lah yang seharusnya mendapatkan porsi yang lebih besar dibanding produk yang lainnya.

Gambaran di atas menunjukkan bahwa adanya kesenjangan antara teori dan praktik dalam pengelolaan bank syariah. Untuk itu perlu upaya untuk meluruskan kembali jalan yang ditempuh oleh bank syariah supaya harapan yang disandarkan padanya bisa tercapai. Hal tersebut penting mengingat keberadaan bank syariah yang sudah sedemikian marak dan masyarakat juga meresponnya secara apresiatif. Upaya tersebut perlu dilakukan secara komprehensif, baik dari internal bank syariah sendiri maupun dari eksternal bank syariah.

Secara internal, bank syariah harus mengevaluasi kembali kinerjanya supaya memastikan bahwa apa yang telah diraihnya telah sesuai dengan apa yang seharusnya/ normatifnya. Meskipun tidak dipungkiri bahwa manajemen bank syariah berkepentingan terhadap perolehan pendapatan/laba yang maksimal, namun perlu juga adanya upaya mensinergikan tujuan tersebut dengan ketaatan pada kaidah syariah. Dengan demikian, manajemen bank syariah bisa memberikan kepastian kepada para pemangku kepentingan (stakeholder) bahwa apa yang mereka capai telah "sempurna" secara materi maupun secara syar'i.

Di sisi lain, perlu juga dorongan dari eksternal bank syariah untuk menjadikan produk dengan prinsip bagi hasil sebagai pilihan utama dalam bertransaksi. Bank Indonesia sebagai regulator dan pengawas harus memberikan perhatian yang lebih besar untuk memastikan bahwa prinsip bagi hasil 
telah terlaksana dengan baik. Secara tegas Bank Indonesia seharusnya menggunakan parameter yang berbeda dalam menilai kinerja bank syariah dibanding bank konvesional. Parameter tersebut harus mencantumkan poin tentang ketaatan bank syariah terhadap prinsip syariah. Selain itu, Bank Indonesia juga harus memberikan dorongan berupa insentif khusus bagi bank syariah yang mengimplementasikan prinsip bagi hasil.

Nasabah dan masyarakat sebagai pengguna bank syariah juga perlu diperhatikan. Perlu edukasi kepada masyarakat tentang produk berbasis bagi hasil sehingga mereka bisa secara langsung merasakan perbedaan utama antara bertransaksi dengan bank syariah dan bank konvensional. Ketika nasabah dan masyarakat telah memiliki pemahaman yang bagus mengenai produk bagi hasil, maka sinergi antara bank syariah dan nasabah menjadi modal kuat untuk mencapai tujuan bank syariah, yaitu perekonomian yang kuat yang berujung pada kesejahteraan, baik materi maupun ukhrawi.

Merujuk pada uraian di atas, maka artikel ini berfokus pada telaah tentang upaya-upaya yang diperlukan guna mendorong bank syariah untuk mengeliminasi produk murabahah dan menggantinya dengan produk berbasis bagi hasil. Pada bagian kedua dari artikel ini disajikan tentang muhasabah (introspeksi diri) bank syariah atas apa yang telah dicapainya. Selanjutnya, pada bagian ketiga artikel ini diajukan berbagai alternatif upaya guna menuju maksimalisasi implementasi prinsip bagi hasil, di mana implementasi tersebut memerlukan kerjasama dari pihak internal maupun eksternal bank syariah. Pada bagian terakhir disajikan simpulan.

Usia bank syariah di Indonesia telah mencapai 21 tahun. Berdasarkan pengalaman selama rentang waktu tersebut, ada baiknya jika bank syariah ber-muhasabah, mengintrospeksi diri, apakah jalan yang ditempuh selama ini benar adanya. Muhasabah bisa dilakukan dengan menelisik ulang alasan di balik keberadaan bank syariah.

Awal kelahiran bank syariah dilandasi dengan kehadiran dua gerakan renaissance Islam modern, yaitu neorevivalis dan modernis. Tujuan utama dari pendirian lembaga keuangan berlandaskan etika ini yaitu sebagai upaya kaum muslimin untuk mendasari segenap aspek kehidupan ekonominya berlandaskan Al Quran dan As-Sunnah. Upa- ya tersebut dilakukan dengan menerapkan sistem profit and loss sharing atau bagi hasil (Antonio 2003:18).

Sistem bagi hasil menjadi kunci dalam operasional bank syariah. Bahkan istilah tersebut yang pertama kali dipakai untuk menyebut bank syariah secara formal dalam dokumen Negara Indonesia, tepatnya Undang-Undang No. 7 tahun 1992 tentang Perbankan Bagi Hasil (Muhammad 2005:15). Selanjutnya Undang-Undang tersebut mengalami proses penyempurnaan melalui beberapa perubahan yaitu UU No. 10 Tahun 1998, UU No 23 Tahun 1999, UU No 3 Tahun 2004, dan terakhir, UU Nomor $21 \mathrm{Ta}-$ hun 2008.

Keberadaan prinsip bagi hasil pada berbagai undang-undang tersebut masih penting. Berikut kutipan Penjelasan UU No 21 Tahun 2008 yang menyebutkan tentang posisi prinsip bagi hasil dalam perbankan syariah:

"Prinsip Perbankan Syariah merupakan bagian dari ajaran Islam yang berkaitan dengan ekonomi. Salah satu prinsip dalam ekonomi Islam adalah larangan riba dalam berbagai bentuknya, dan menggunakan sistem antara lain prinsip bagi hasil (penebalan huruf oleh penulis). Dengan prinsip bagi hasil, Bank Syariah dapat menciptakan iklim investasi yang sehat dan adil karena semua pihak dapat saling berbagi baik keuntungan maupun potensi risiko yang timbul sehingga akan menciptakan posisi yang berimbang antara bank dan nasabahnya. Dalam jangka panjang, hal ini akan mendorong pemerataan ekonomi nasional karena hasil keuntungan tidak hanya dinikmati oleh pemilik modal saja, tetapi juga oleh pengelola modal."

Berdasarkan uraian di atas maka dapat teridentifikasi bahwa prinsip bagi hasil merupakan salah satu dari prinsip dalam operasional bank syariah. Prinsip operasional bank syariah yang lain yaitu titipan/ simpanan, jual beli, sewa, dan jasa. Namun demikian, dalam dokumen UU No 21 Tahun 2008 tersebut, penjelasan mengenai prinsip yang lain tersebut tidak ditemukan. Hal ini menjadi salah satu alasan bahwa kedudukan prinsip bagi hasil masih tetap istimewa 
dibanding prinsip-prinsip yang lain.

Sebagai prinsip utama, maka jejak prinsip tersebut seharusnya terlihat secara jelas pada implementasi produk perbankan syariah. Namun kenyataan menunjukkan sebaliknya, justru produk non bagi hasil yang mendominasi produk perbankan syariah, yaitu produk murabahah yang menggunakan prinsip jual beli. Bukankah bank syariah itu bukan entitas bisnis yang bergerak di bidang perdagangan?. Tentu ini merupakan fenomena yang aneh.

\section{HASIL DAN PEMBAHASAN}

Bagi hasil disebut juga mudharabah atau qiradh. Akad ini merupakan bentuk kerjasama antara pemilik modal dan seseorang yang dilandasi oleh rasa tolongmenolong (Hasan 2003:169). Akad tersebut muncul ketika ada orang yang mempunyai modal tetapi tidak mempunyai keahlian dalam mengelolanya. Di sisi lain, ada juga orang yang mempunyai modal maupun keahlian, akan tetapi tidak memiliki waktu maupun tenaga. Selanjutnya, dengan menggunakan akad mudharabah kedua pihak tersebut bekerjasama dalam pengelolaan suatu usaha.

Akad mudharabah dibenarkan dalam Islam sebagaimana ketentuan Alloh SWT dalam firman Alloh SWT yaitu:

“... dan dari orang-orang yang berjalan di muka bumi mencari sebagian karunia Alloh SWT..."(Al Muzzammil:20)

"Apabila telah ditunaikan shalat maka bertebaranlah kamu di muka bumi dan carilah karunia Alloh SWT...”(Al Jumuah:10)

"Tidak ada dosa (halangan) bagi kamu untuk mencari karunia Tuhanmu..."(Al Baqarah:198)

Ayat-ayat tersebut menunjukkan argumentasi adanya mudharabah yang berarti melakukan perjalanan usaha (Antonio 2003:95). Ayat-ayat tersebut juga menguatkan maksud adanya akad mudharabah yaitu terwujudnya kerja sama harta dan amal karena Allah tidak mensyariatkan satu akad kecuali untuk mewujudkan kemaslahatan dan menolak kerusakan (Sabiq 1994:221).

Sebenarnya sistem mudharabah sudah berlaku sejak sebelum Islam datang. Sebagaimana diketahui bahwa Khadijah binti
Kuwalid adalah wanita kaya yang selalu memberikan uangnya kepada orang lain untuk dijalankan sebagai modal usaha. Rasulullah SAW pun pernah membawa dagangan Khadijah ke Syiria. Perniagaan itu mendapat keuntungan yang banyak dan beliau pun mendapat bagian dari keuntungan tersebut.

Pada bank syariah, akad mudharabah dijadikan prinsip dasar operasional sekaligus pembeda antara bank syariah dengan bank konvensional (Antonio 2003:60). Bank syariah menggunakan akad tersebut untuk fungsi penghimpunan dana dengan cara berlaku sebagai mudharib (pengelola dana). Sebaliknya, bank syariah bertindak sebagai shohibul maal (pemilik dana) ketika menjalankan fungsi sebagai penyalur dana.

Dengan menggunakan akad mudharabah, bank syariah mendapatkan keuntungan dari bagi hasil dengan pihak ketiga. Di sisi lain, bank syariah juga berkewajiban untuk membagikan keuntungan tersebut kepada nasabah. Oleh karena adanya kecenderungan perolehan keuntungan yang tidak pasti, maka bank syariah kurang patuh dalam pengimplementasian akad ini untuk menyalurkan dana. Sebagaimana disebutkan pada bagian sebelumnya, bank syariah lebih menyukai untuk menggunakan akad murabahah (jual beli) untuk menyalurkan dananya. Alasannya adalah dengan menggunakan akad murabahah, bank syariah mendapatkan keuntungan yang bersifat tetap dan pasti yaitu berupa marjin.

Tentu saja alasan tersebut tidak bisa dibenarkan karena tujuan dari muamalah dalam Islam bukan semata keuntungan, melainkan juga kemaslahatan umat dan ridho Alloh SWT. Harapannya, apa yang sudah benar dalam perumusan prinsip operasional bank syariah yaitu mudharabah, bisa membawa bank syariah menjadi pelopor kemaslahatan umat dunia dan akhirat. Untuk itu, perlu upaya untuk mengawal implementasi prinsip bagi hasil pada bank syariah.

Menurut bahasa, bank berasal dari bahasa Italia banque atau Italia banca yang berarti bangku. Para bankir Florence pada masa Renaissans melakukan transaksi mereka dengan duduk di belakang meja penukaran uang, berbeda dengan pekerjaan kebanyakan orang yang tidak memungkinkan mereka untuk duduk sambil bekerja (Hoggson 1926). Berdasarkan makna tersebut nampak bahwa kegiatan bank berupa aktivitas jasa yang terkait dengan uang dan pelakunya tidak memerlukan mobilitas. 
Menurut Undang-Undang Republik Indonesia No 10 Tahun 1998 usaha perbankan meliputi tiga kegiatan, yaitu menghimpun dana, menyalurkan dana, dan memberikan jasa bank lainnya. Seperti halnya pada bank konvensional, menurut UU RI No 21 Tahun 2008 bank syariah melakukan fungsi penghimpunan dan penyaluran dana masyarakat. Akan tetapi, bank syariah dibebani tugas tambahan berupa fungsi sosial yaitu menerima dana zakat, infak, sedekah, hibah, wakaf dan lainnya untuk disalurkan ke organisasi pengelola zakat

Asal-muasal perbankan syariah pada beberapa literatur tentang perbankan syariah yang popular dimulai dengan berdirinya Islamic Rural bank di desa Mit Ghamr pada tahun 1963 di Kairo, Mesir (Antonio 2003:18 dan Salman 2012:1). Sedangkan di Indonesia, bank syariah pertama yang berdiri yaitu Bank Muamalat Indonesia hadir pada tahun 1991. Fakta tersebut menunjukkan keberadaan bank syariah sangat jauh tertinggal dengan keberadaan bank konvensional yang telah berdiri pertama kali di dunia pada tahun 1690 tepatnya di Inggris dan ada di Indonesia pada tahun 1828 (Hoggson 1926).

Meskipun demikian, sebagaimana telah disajikan pada bagian sebelumnya mengenai filosofi prinsip bagi hasil, kegiatan perbankan telah ada sebelum Islam datang. Namun secara kelembagaan, bank syariah teridentifikasi keberadaannya pada masa Bani Abbasiyah pada tahun 750 (Yasin 2009:131). Pada masa tersebut, fungsi perbankan dilakukan oleh satu individu. Pada masa itu perbankan berkembang dengan pesat seiring dengan beredarnya berbagai mata uang dan kegiatan perekonomian lintas negara. Dengan demikian dapat diketahui bahwa hakikat bank telah lama dipraktikkan oleh kaum muslim dan bahkan menjadi rujukan bagi peradaban di Eropa hingga mereka bisa mengembangkannya.

Perkembangan bank syariah modern tercatat di Pakistan dan Malaysia sekitar tahun 1940 , yang pada waktu itu adalah usaha pengelolaan dana jamaah haji secara nonkonvensional (Salman 2012:2). Di Indonesia, gagasan mengenai bank syariah muncul pada pertengahan tahun 1970 . Bank syariah pertama di Indonesia adalah Bank Muamalat pada tahun 1991. Kegiatan bank syariah modern lebih kompleks antara lain tabungan, deposito, giro, obligasi, pembiayaan, costumer network financing, kartu kredit, kartu debit, dan sebagainya.
Perumusan mudharabah sebagai prinsip dasar operasi bank syariah tentunya bukan tanpa maksud dan melalui pertimbangan yang masak. Secara umum, landasan dasar syariah mudharabah lebih mencerminkan anjuran untuk melakukan usaha (Antonio 2003:97). Jadi penekanan pada akad mudharabah ini adalah pada keberadaan usaha riil yang dilakukan dengan menggunakan modal dari salah satu pihak. Selanjutnya, usaha tersebut menjadi inti yang darinya muncul keuntungan yang akan dibagihasilkan.

Pada bank syariah, aplikasi akad mudharabah diterapkan untuk produk-produk pembiayaan dan pendanaan. Pada sisi penghimpunan dana, mudharabah diterapkan pada tabungan berjangka dan deposito spesial. Sedangkan pada sisi pembiayaan, mudharabah diterapkan untuk pembiayaan modal kerja dan investasi khusus (Antonio 2003:97).

Data perbankan syariah di Indonesia menunjukkan bahwa penerapan akad mudharabah lebih dominan pada produk pendanaan dibanding produk pembiayaan. Tabungan dan deposito pada beberapa bank syariah menggunakan akad ini antara lain Bank Syariah Mandiri, Bank Bukopin Syariah, Bank Muamalat, Bank Victoria Syariah, Bank BCA Syariah, dan BRI Syariah. Begitu pula kecenderungan serupa juga terjadi secara global (Khan 2010).

Fenomena tersebut diindikasikan disebabkan tingginya risiko mudharabah terutama pada penerapan pembiayaan (Antonio 2003:98). Risiko tersebut antara lain side streaming, lalai/kesalahan yang disengaja, dan penyembunyian keuntungan. Kurniawati (2008) menyimpulkan risiko tersebut muncul akibat adanya masalah keagenan antara bank syariah dan nasabah pembiayaan.

Apapun risiko yang muncul pada akad mudharabah, seyogyanya bank syariah tidak menjadikannya sebagai alasan penghindaran implementasi akad tersebut. Sebab, kembali lagi pada definisi bank syariah sebagaimana tercantum dalam Pasal 1 UU No 21 Tahun 2008 yang menyatakan bahwa bank adalah badan usaha yang menghimpun dana dari masyarakat dalam bentuk simpanan dan menyalurkannya kepada masyarakat dalam bentuk kredit dan/atau bentuk lainnya dalam rangka meningkatkan taraf hidup rakyat.

Berdasarkan definisi tersebut jelas bahwa fokus utama operasi bank syariah yaitu 
menghimpun dan menyalurkan dana atau sering juga disebut sebagai fungsi intermediasi. Namun fakta menunjukkan bahwa bank syariah menggunakan akad mudharabah untuk menjalankan fungsi pendanaan, sedangkan untuk fungsi pembiayaannya bank syariah menggunakan akad murabahah.

Berdasarkan analisis singkat mengenai implementasi produk dengan prinsip jual beli dan bagi hasil di atas, maka terlihat bahwa ada alasan besar mengapa bank syariah "memilih" kebijakan tersebut. Kebijakan tersebut tentunya tidak lepas dari kepentingan bank syariah, yaitu untuk bisa menjalankan fungsi intermediasinya dengan lancar dan mendapatkan hasil yang maksimal.

Apapun motivasi bank syariah, tidak seharusnya ada pengabaian prinsip bagi hasil. Jangan sampai masyarakat menilai bahwa prinsip bagi hasil hanya sebatas teori karena mereka tidak menemui praktiknya di lapangan. Tentu saja kejadian ini tidak boleh dibiarkan. Harus ada peringatan kepada bank syariah akan pentingnya implementasi bagi hasil. Selanjutnya baik bank syariah maupun pihak-pihak yang terkait harus ikut berperan serta dalam mendorong implementasi prinsip bagi hasil tersebut. Dengan demikian, bank syariah dapat berjalan sesuai dengan apa yang diharapkan.

Setelah melewati proses muhasabah, maka diperoleh pemahaman bahwa keberadaan prinsip bagi hasil pada bank syariah adalah mutlak dan penting. Prinsip tersebut harus terus dijaga dan dikawal agar bisa dilaksanakan dengan baik oleh bank syariah. Dengan demikian, harapan yang disandarkan pada bank syariah akan bisa tercapai dan ada jaminan bahwa pencapaian tersebut seirama dengan kaidah syariah Islam.

Upaya untuk menerapkan prinsip bagi hasil pada bank syariah memerlukan kerjasama dari berbagai pihak, bukan hanya bank syariah saja yang menanggungnya (Khan dan Bhatti 2008). Secara umum, upaya implementasi prinsip bagi hasil bisa dikelompokkan menjadi dua, yaitu dari pihak internal dan eksternal bank syariah yang terdiri atas pemerintah, masyarakat, akademisi, dan cendekiawan muslim.

Upaya implementasi prinsip bagi hasil dari sisi internal bank syariah memerlukan kerja keras baik dari manajemen, pemegang saham, dewan komisaris, dan dewan pengawas syariah. Semua elemen tersebut memiliki fungsi dan peran tersendiri yang harus diharmonisasikan dengan semangat yang tunggal yaitu mentaati syariat Alloh SWT dalam mengelola bank syariah.

Beberapa penelitian tentang prinsip bagi hasil menyatakan bahwa faktor yang menyebabkan gagalnya akad tersebut yaitu adanya agency problem (Aggarwal dan Yousef 2000; Presley 2000 dan Kurniawati 2008). Agency problem tersebut berawal dari adanya asymmetry information yang selanjutnya mengakibatkan moral hazard yang dilakukan oleh mudharib.

Guna mengatasi permasalahan tersebut bank syariah seharusnya bisa mengantisipasi dengan baik, salah satunya yaitu dengan mengelola dana (withdrawals) untuk mengoptimalkan dana nasabah dalam portfolio pembiayaan (Ismal 2011, 2012). Selain itu, bank syariah juga harus memaksimalkan fungsi analis kredit/pembiayaan. Fungsi tersebut harus berlaku selektif dan hati-hati (prudent) mencari usaha yang benar-benar halal, aman, dan menguntungkan karena keuntungan yang kongkret dan benar-benar terjadi itulah yang dibagikan.

Tantangan tersebut ditandingkan dengan target manajemen bank syariah dalam mencapai nilai tertentu dalam penyaluran dana. Ada kesan bahwa proses kelayakan kredit/pembiayaan bukan merupakan hal penting atau sekedar formalitas saja. Bank syariah terlalu mudah memberikan pembiayaan demi mencapai target jumlah penyaluran dana yang telah ditetapkan oleh manajemen. Dengan demikian, fungsi analis kredit/pembiayaan menjadi tidak maksimal.

Tantangan target tersebut seharusnya menjadi peluang bagi bank syariah untuk "mendidik" nasabah/calon nasabahnya supaya menggunakan produk bagi hasil agar kedua belah pihak mendapatkan keuntungan dan keadilan. Bank syariah harus menyadari bahwa produk berbasis bagi hasil merupakan pilihan alokasi modal yang efisien dan adil sebab imbal balik yang diperoleh didasarkan pada kinerja dan kelayakan usaha dari nasabah. Dengan skema tersebut, ada penyatuan kepentingan antara pemilik dan pengelola modal, yaitu keduanya berharap memperoleh keuntungan dan usahanya langgeng.

Oleh karena itu, bank syariah tidak bisa hanya melepas begitu saja dananya, melainkan juga harus mendampingi, memantau, dan mengevaluasi kinerja mudhar$i b$, supaya mengurangi asymmetry information. Selain itu, harus ada juga upaya bank 
syariah untuk memberikan bekal manajerial dan spiritual sebagai upaya untuk meminimalisir moral hazard. Upaya tersebut dilakukan dengan tujuan agar diperoleh pemahaman akan kepentingan kedua belah pihak dalam produk berbasis bagi hasil. Dengan demikian, tercipta hubungan yang harmonis antara bank syariah dan nasabah.

Ada baiknya bank syariah merujuk pada praktik lembaga keuangan non perbankan. Meskipun cakupan usahanya lebih sempit, namun mereka berhasil mencapai tujuan sosial yang dibuktikan dari dominannya porsi produk berbasis bagi hasil pada operasi mereka (Timberg 2003). Lembaga keuangan non perbankan tersebut meliputi Baitul Maal wa Tamwil (BMT), Modal Ventura, Bank Perkreditan Rakyat Syariah (BPRS), Koperasi Jasa Keuangan Syariah (KJKS), dan Koperasi Pesantren (Kopontren). Bukti tersebut menunjukkan bahwa implementasi produk berbasis bagi hasil adalah sebuah keniscayaan asalkan diupayakan secara maksimal.

Ide tersebut senada dengan yang disampaikan oleh Mulya E. Siregar, Direktur Direktorat Perbankan Syariah BI dalam kata pengantar Outlook Perbankan Syariah 2011 yang menyatakan bahwa perlunya inovasi baru pada perbankan syariah. Mengamati perkembangan persaingan usaha kedepan yang semakin ketat, maka strategi pengembangan daya saing bank syariah akan semakin diarahkan kepada Coopetition Strategy yang memadukan semangat kerjasama dalam persaingan terutama terhadap bank dengan nasabahnya, sehingga akan tercipta win-win solution dalam menjalankan bisnis bank dengan tujuan akhir adalah kemanfaatan industri perbankan syariah yang sebesar-besarnya bagi masyarakat.

Upaya lain yang harus ditempuh oleh bank syariah untuk mengatasi agency problem pada implementasi prinsip bagi hasil yaitu dengan menerapkan good corporate governance (GCG) dengan maksimal dan dilandasi oleh kesadaran spiritual yang tinggi. Bank syariah harus menyadari sepenuhnya bahwa GCG merupakan salah satu solusi untuk mengurangi risiko dan sekaligus memicu peningkatan kinerja.

Peran pemerintah dalam mendorong perbankan syariah dalam mengelola risiko salah satunya yaitu melalui pemberlakuan Peraturan Bank Indonesia (PBI) Nomor 11/33/PBI/2009 tanggal 7 Desember 2009 tentang Pelaksanaan Good Corporate Gover- nance Bagi Bank Umum Syariah dan Unit Usaha Syariah yang berlaku sejak tanggal 1 Januari 2010. Upaya tersebut dimaksudkan untuk memperkuat ketahanan sistem perbankan menghadapi risiko ke depan, termasuk dalam hal ini dampak ketidakpastian perekonomian global saat ini yang dikuatirkan berkepanjangan. Oleh karena itu, pada tahun 2012, Bank Indonesia mendorong penguatan tata kelola usaha atau GCG dan pengelolaan risiko pada bank syariah.

Pelaksanaan GCG telah menjadi daya tarik tersendiri bank syariah. Hal ini dibuktikan dari semangat bank syariah dalam mengimplementasikan dan melaporkan GCG. Media komunikasi bank syariah berupa laman mereka menyajikan hal tersebut. Paling tidak sampai saat ini telah berjalan dua periode sejak pengimplementasian PBI 11/33/PBI/2009, sehingga data terkait dengan GCG bank syariah telah tersedia untuk tahun 2010 dan 2011.

Keberadaan PBI No. 11/33/PBI/2009 tersebut melengkapi regulasi tentang penilaian tingkat kesehatan bank syariah yaitu PBI No. 21 Tahun 2008. Pada peraturan tersebut, aspek pengelolaan atau manajemen menjadi salah satu faktor penilaian tingkat kesehatan bank syariah. Berbagai upaya pemerintah tersebut merupakan salah satu wujud dari dorongan Bank Indonesia dengan pendekatan regulasi untuk menopang pertumbuhan perbankan syariah. Pertumbuhan tersebut diselaraskan pula dengan kepastian akan ketaatan bank syariah kepada kaidah etika dan prinsip syariah.

Terdapat bukti empiris yang menunjukkan bahwa penerapan bagi hasil ditentukan oleh seberapa baik implementasi GCG pada bank syariah (Dar dan Presley 2000; Sehrish et al. 2012). Kedua penelitian tersebut menyatakan bahwa implementasi GCG bersama dengan faktor kecukupan modal pada bank syariah digunakan sebagai parameter pengukuran penerapan bagi hasil.

Upaya lain yang bisa dilakukan oleh pemerintah yaitu dengan memberikan insentif kepada bank syariah agar mengimplementasikan produk berbasis bagi hasil. Insentif tersebut bisa berupa pemberian penilaian yang bobotnya lebih besar pada aktivitas tersebut. Dengan demikian, bank syariah dipicu untuk berlomba-lomba menggiatkan produk berbasis bagi hasil dengan harapan mendapatkan penilaian kinerja yang bagus oleh pemerintah maupun masyarakat. 
Ide tersebut menarik untuk ditindaklanjuti mengingat penilaian kinerja bank syariah yang ditetapkan oleh Bank Indonesia tidak memuat perspektif ketaatan pada kaidah syariah. Pengukuran kinerja bank syariah di Indonesia mengacu pada Peraturan Bank Indonesia No. 21 Tahun 2008 tentang Penilaian Tingkat Kesehatan Bank Syariah.

Pada peraturan tersebut terdapat enam faktor penentu tingkat kesehatan bank syariah, yaitu capital, assets, management, equity, liquidity, dan sensitivity to market yang disingkat dengan CAMELS. Kenyataannya, penggunaan CAMELS juga berlaku untuk bank konvesional. Hal ini tercantum pada Peraturan Bank Indonesia No. 6/10/ PBI/2004 tanggal 12 April 2004 tentang Sistem Penilaian Tingkat Kesehatan Bank Umum dan Surat Edaran Bank Indonesia No. 6/23/DPNP tanggal 31 Mei 2004.

Beberapa penelitian menggunakan ukuran lain untuk menilai kinerja bank syariah. Kinerja bank syariah dinilai berdasarkan kualitas produk, profitabilitas, dan produktivitas (Ahmad 2010; Usman dan Khan 2012; Al-Farisi dan Hendrawan 2012). Selain itu, peneliti lain membuktikan beberapa ukuran untuk menilai kinerja bank syariah, yaitu risiko pembiayaan yang rendah dan efisiensi dalam pengelolaan pengeluarannya (Sehrish et al. 2012), likuiditas (Ika dan Abdullah 2011), kualitas aset dan kecukupan modal (Kouser dan Saba 2012).

Fakta mengenai pengukuran kinerja bank syariah tersebut tidaklah wajar mengingat terdapat perbedaan yang mendasar antara bank syariah dan bank konvensional. Meskipun keduanya sama-sama ada di ranah ekonomi, namun jelas bahwa bank syariah memiliki cakupan yang lebih luas. Pertanggungjawaban bank syariah tidak hanya semata pada aspek ekonomis semata, melainkan juga aspek ketaatan pada syariat Allah SWT. Poin ketaatan kepada Allah SWT itulah yang seharusnya dimasukkan dalam pengukuran kinerja bank syariah. Dengan demikian, bank syariah tidak terjebak dalam aktivitas ekonomis yang tidak seiring dengan perintah syariah.

Ahmed (2002) menunjukkan teknik pengukuran kinerja bank syariah yang memperhatikan penerapan prinsip bagi hasil. Teknik tersebut dilakukan dengan cara mengklasifikasikan kinerja berdasarkan peran bank syariah, apakah dipandang sebagai shohibul maal, mudharib, atau keduanya sekaligus (Antonio, 2003, 97). Peng- klasifikasian tersebut juga seiring dengan pemodelan bank syariah ketika berfungsi sebagai penyedia likuiditas (Ahmed, 2002). Ketika sebagai shahibul maal, bank syariah berfokus pada sisi aset. Sedangkan ketika berperan sebagai mudharib, fokusnya pada sisi liabilitas. Dengan demikian, penggunaan angka kuantitatif tetap bisa dilakukan dengan catatan memperhatikan kesesuaiannya dengan prinsip operasional bank syariah yaitu bagi hasil. Lebih penting lagi, angka tersebut seharusnya mendapatkan bobot yang lebih besar dibanding angka kuantitatif lainnya seperti yang biasa digunakan untuk mengukur kinerja bank konvensional.

Penilaian tingkat kesehatan bank syariah yang berbeda dan memasukkan nilai spiritual disampaikan oleh Triyuwono (2011). Penilaian tingkat kesehatan bank syariah tersebut dinamakan ANGELS. ANGELS merupakan singkatan dari Amanah management, Non-economic wealth, Give out, Earning, Capital and assets, Liquidity and sensitivity to market, dan Socio-economic wealth. Masing-masing faktor dari ANGELS merupakan bagian dari "proses", "hasil", dan "stakeholders". Semua faktor dalam CAMELS ada dalam ANGELS, kecuali faktor Non-economic wealth, Give out, dan Socio-economic wealth. Sedangkan pada faktor Amanah management terdapat tambahan jika dibandingkan dengan faktor management pada CAMELS.

Masyarakat sebagai nasabah bagi bank syariah juga harus diperhatikan mengingat tingkat pemahaman mereka tentang produk bank syariah yang masih rendah (Awwan dan Bukhari 2011; Pepinsky 2011). Masyarakat harus disadarkan akan manfaat maupun keunggulan dari produk berbasis bagi hasil, baik untuk produk tabungan maupun pembiayaan. Penyadaran tersebut menjadi tanggung jawab bersama antara bank syariah, pemerintah, juga pada alim ulama.

Selama ini, bank syariah telah banyak melakukan sosialisasi kepada masyarakat. Bank syariah membuka gerai di tempattempat umum, melakukan sosialisasi ke kampus dan sekolah, menampilkan profil mereka di media massa, dan sebagainya. Selain mendekatkan diri kepada masyarakat, bank syariah seharusnya juga memberikan penjelasan kepada mereka tentang pembeda utama dari bank syariah dan bank konvensional, yaitu tidak adanya bunga serta penerapan sistem bagi hasil.

Namun, pada praktiknya para karyawan di bank syariah masih kurang memi- 
liki pemahaman tentang filosofi praktik perbankan syariah. Mereka masih belum memiliki bekal pemahaman yang memadai untuk mengedukasi masyarakat atau nasabah. Karyawan bank syariah masih sangat terbatas pengetahuannya tentang perbankan syariah. Hal ini dapat dimaklumi mengingat latar belakang pendidikan mereka yang bukan dari ekonomi syariah. Bahkan pada level manajer, karyawan bank syariah banyak yang berasal dari bank konvensional.

Tapi itu semua bukan menjadi alasan, bukankah pada tiap bank syariah telah memiliki Dewan Pengawas Syariah (DPS) yang terdiri atas orang-orang yang memiliki kompetensi yang bagus baik secara syariah maupun ekonomi. Fungsi DPS tersebut seharusnya bisa dimaksimalkan dengan menyuplai pemahaman syariah, khususnya ekonomi syariah kepada sumber daya insani yang dimiliki oleh bank syariah. Dengan demikian, para karyawan memiliki pemahaman yang memadai guna melayani dan mengedukasi nasabah dan masyarakat.

Upaya tersebut menjadi catatan tersendiri bagi para pegiat di institusi pendidikan untuk menyediakan sumber daya insani yang berkualitas serta memiliki nilai spiritualitas yang tinggi. Dengan demikian, bekal sumber daya insani tersebut menjadi salah satu tumpuan penting bagi bank syariah untuk bisa beroperasi secara profesional serta tetap tunduk pada kaidah syariah, termasuk dalam mengimplementasikan prinsip bagi hasil (Markum 2007).

Upaya untuk menyediakan sumber daya insani di bidang ekonomi syariah telah dilakukan. Hingga saat ini, banyak lembaga-lembaga pendidikan yang menawarkan program pelatihan maupun mata kuliah Ekonomi Islam, Keuangan Islam dan Perbankan Syariah baik pada tingkat Sarjana (S1) maupun tingkat Pascasarjana (S2 dan S3) (Djohar 2006). Pada tataran pendidikan formal terdapat Program Studi Ekonomi Islam Fakultas Ilmu Agama Islam Universitas Islam Indonesia, SBI Institute, SEBI, STEI Yogyakarta, Jurusan Ekonomi Islam STAIN Surakarta, UIN Syarif Hidayatullah Ciputat, UIN Yogyakarta, IAIN Medan, dan Fakultas Ekonomi UNAIR, STEI Tazkia, dan Jurusan Timur Tengah dan Islam UI serta upaya lain dari beberapa universitas Islam dan sekolah tinggi Islam yang cukup banyak. Semua institusi tersebut diharapkan berkontribusi dalam menyediakan sumber daya insani yang mumpuni dan memiliki pemahaman yang kuat mengenai syariat Islam, khususnya yang berkaitan dengan bidang ekonomi.

Hal yang tak kalah penting yaitu perlunya upaya terus-menerus dari para cendekiawan muslim/ekonom muslim untuk terus mengevaluasi dan menyuplai berbagai alternatif solusi dan inovasi dalam mendukung tumbuh berkembangnya bank syariah di Indonesia. Bekal pengetahuan tentang normanorma ekonomi syariah harus menjadi senjata dalam mengawal praktik bank syariah agar tetap ada dalam bingkai syariah serta memastikan bahwa paradigma tersebut memiliki keunggulan baik secara material maupun spiritual.

Upaya tersebut antara lain diwujudkan dalam bentuk pembicaraan perkembangan Ekonomi Islam yang dilakukan melalui kegiatan pelatihan, seminar, simposium, konferensi, kajian buku dan kegiatan lain yang mengkaji lebih mendalam mengenai perkembangan Ekonomi Islam dan aplikasinya dalam dunia ekonomi dan bisnis. Di antara lembaga pelatihan itu antara lain Tazkia Institute, Shariah Economic and Banking Institute (SEBI), Masyarakat Ekonomi Syariah (MES), Pusat Pelatihan dan Pengembangan Sumber Daya Mandiri (PPSDM), Muamalat Institute, Karim Bussiness Consulting, dan Divisi Perbankan Syari'ah Institute Bankir Indonesia (IBI).

Berbagai upaya tersebut melibatkan banyak pihak. Harus ada kesepakatan di antara mereka bahwa memperjuangkan implementasi prinsip bagi hasil pada bank syariah adalah hal yang harus diprioritaskan. Ini semua merupakan satu bentuk perjuangan untuk memfasilitasi kaum muslim untuk mengimplementasikan keimanan mereka dalam bidang muamalah. Dengan demikian, tujuan kesejahteraan masyarakat baik secara material dan spiritual bisa tercapai.

\section{SIMPULAN}

Keberadaan bank syariah di Indonesia memiliki peran yang vital dalam pencapaian tujuan kesejahteraan masyarakat. Hanya saja, terdapat penyimpangan dalam praktik bank syariah yaitu adanya indikasi pengabaian prinsip bagi hasil dalam operasionalnya. Hal tersebut dibuktikan dari minimnya implementasi produk berbasis bagi hasi yaitu mudharabah dan musyarakah.

Namun demikian, adanya penyimpangan tersebut tidak menjadikan bank syariah dijauhi ataupun ditinggalkan sama sekali. Justru fakta tersebut menjadi titik acuan 
untuk melakukan muhasabah (introspeksi) bagi bank syariah supaya kembali kepada khittah (jalan perjuangan). Bank syariah harus diingatkan bahwa prinsip bagi hasil adalah penting dan tidak boleh diabaikan karena prinsip tersebut yang menjadi dasar operasional.

Terkait dengan itu, maka perlu sinergi dari berbagai pihak untuk mendukung bank syariah dalam mengimplementasikan prinsip bagi hasil. Masing-masing pihak memberikan kontribusi penting dan satu dengan lain saling terkait dan mendukung bank syariah.

Pada akhirnya, dengan pengembalian bank syariah ke jalur yang seharusnya, maka eksistensi bank syariah bisa dipertanggungjawabkan. Lebih lanjut, bank syariah lah yang menjadi salah satu tumpuan dalam pembangunan dan mewujudkan kesejahteraan masyarakat, dunia dan akhirat.

Ke depannya, perlu adanya kajian yang mendalam tentang model yang paling sesuai untuk mengimplementasikan prinsip bagi hasil pada bank syariah. Kajian tersebut bisa jadi bersifat multidisipliner supaya diperoleh hasil yang komprehensif dan aplikatif. Bank Indonesia juga perlu mendorong pengkajian tersebut karena keberadaan bank syariah telah sedemikian meluas dan pertumbuhannya relatif cepat. Bank Indonesia juga berkewajiban merawat dan melindungi bank syariah, tidak hanya menikmati prestasinya saja.

\section{DAFTAR RUJUKAN}

Aggarwal, R. K., dan Yousef, T. 2000. "Islamic Banks and Investment Financing". Journal of Money, Credit \& Banking. Vol. 32 No.1, hal 93-120.

Ahmad, A. 2010. "Application of Non-Financial Measures for Assessment of Performance of Islamic Banks in Pakistan". Interdisciplinary Journal of Contemporary Research in Business. Vol. 2 No. 7, hal 173-181.

Ahmed, H. 2002. "A Microeconomic Model of An Islamic Bank" Jeddh: Islamic Research And Training Institute - Islamic Development Bank. Vol 59, No 1, hal 40-85.

Antonio, M. S. 2001. Bank Syariah dari Teori ke Praktik. Gema Insani Press. Jakarta

Al-Farisi, A. S., dan Hendrawan, R. 2012. "Effect of Capital Structure on Banks Performance: A Profit Efficiency Approach Islamic and Conventional Banks Case in Indonesia". International Research Journal of Finance \& Economics. 86, hal 6-19.

Awan, H. M., dan Bukhari, K. S. 2011. "Customer's criteria for selecting an Islamic bank: evidence from Pakistan". Journal of Islamic Marketing. Vol 2 No. 1, hal 15-31.

Dar, H. A., dan Presley, J. R. 2000. Lack of Profit Loss Sharing in Islamic Banking; Management and Control Imbalances. Centre for International, Financial and Economics Research Loughborough University. Loughborough. UK.

Djohar. 2006. Pengembangan Pendidikan Nasional Menyongsong Masa Depan. Grafika Indah. Yogyakarta.

Bank Indonesia. 2004. Peraturan Bank Indonesia No. 6/10/PBI/2004 tentang Sistem Penilaian Tingkat Kesehatan Bank Umum

Bank Indonesia. 2004. Surat Edaran Bank Indonesia No. 6/23/DPNP/2004

Bank Indonesia. 2008. PBI No. 21 Tahun 2008 tentang penilaian tingkat kesehatan bank syariah

Bank Indonesia. 2009. Peraturan Bank Indonesia (PBI) Nomor 11/33/PBI/2009 tentang Pelaksanaan Good Corporate Governance Bagi Bank Umum Syariah dan Unit Usaha Syariah

Bank Indonesia. 2011. Outlook Perbankan Syariah 2012. Jakarta

Bank Indonesia. 2012. Outlook Perbankan Syariah 2013. Jakarta

Chong, B. S., dan Liu, M.-H. 2009. "Islamic banking: Interest-free or interestbased?". Pasific-Basin Finance Journal. 17 , hal 20-41.

Hasan, M.A. 2003. Berbagai Macam Transaksi dalam Islam (Fiqh Muamalat). Jakarta. PT Raja Grafindo Persada

Hoggson, N. F. 1926. Banking Through the Ages. New York. Dodd, Mead \& Company

Ismal, R. 2011. "Depositors' withdrawal behavior in Islamic banking: case of Indonesia". Humanomics Vol. 27 No.1, hal 17-38.

Ismal, R.2012. "Formulating withdrawal risk and bankruptcy risk in Islamic banking". International Journal of Islamic and Middle Eastern Finance and Management. Vol. 5 No.1, hal 16-33.

Ika, S. R., dan Abdullah, N. 2011. "A Comparative Study of Financial Performance of Islamic Banks and Conventional Banks in Indonesia". International Journal of 
Business \& Social Science. Vol. 2 No.15, hal 199-207

Iqbal, M. 1998. Challenges Facing Islamic Banking. Edisi 1. Islamic Research And Training Institute - Islamic Development Bank

Khan, M. M., dan Bhatti, M. I. 2008. "Development in Islamic banking: a financial risk-allocation approach". The Journal of Risk Finance, Vol. 9 No.1, hal 13-27.

Khan, F. 2010. "How 'Islamic' is Islamic Banking?". Journal of Economic Behavior \& Organization. 2, hal 76-97

Kurniawati. 2008. Masalah Keagenan (Agency Problem) dalam Kontrak Mudharabah di Bank Syariah. Tesis tidak dipublikasikan. Universitas Indonesia Program Pascasarjana

Kouser, R., dan Saba, I. 2012. "Gauging the Financial Performance of Banking Sector using CAMEL Model: Comparison of Conventional, Mixed and Pure Islamic Banks in Pakistan". International Research Journal of Finance \& Economics. 82, hal 67-88.

Markum, M. E. 2007. Pendidikan Tinggi dalam Perspektif Sejarah dan Perkembangannya di Indonesia. Jakarta. Penerbit Universitas Indonesia.

Muhammad. 2005. Pengantar Akuntansi Syari'ah (edisi 2 ). Jakarta. Salemba Empat.

Pepinsky, T. B. 2012. "Development, Social Change, and Islamic Finance in Contemporary Indonesia". World Development. 14, hal 11-23

Presley, J. R dan Dar, H. A. 2000. "Lack of Profit Loss Sharing in Islamic Banking: Management and Control Imbalances".
Economic Research Paper. No. 00/24, summer, Loughborough University

Sabiq, S. 1994. Fiqih Sunnah. Pena Publishing. Jakarta.

Salman, K. R. 2012. Akuntansi Perbankan Syariah Berbasis PSAK Syariah. Akademia Permata. Padang.

Sehrish, S., Saleem, F., Yasir, M., Shehzad, F., dan Ahmed, K. 2012. "Financial Performance Analysis of Islamic Banks and Conventional Banks in Pakistan: A Comparative Study". Interdisciplinary Journal of Contemporary Research in Business. Vol 4 No. 5, hal 186-200.

Timberg, T. A. 2003. Islamic Banking and Its Potential Impact, Paving the Way Forward for Rural Finance An International Conference on Best Practices Risk Management : Islamic Financial Policies. World Council of Credit Unions, Inc.

Triyuwono, I. 2011. "Angels: Sistem Penilaian Tingkat Kesehatan Bank Syariah". Jurnal Akuntansi Multiparadigma. Vol. 2 No.1, hal 21 - 43.

Usman, A., dan Khan, M. K. 2012. "Evaluating the Financial Performance of Islamic and Conventional Banks of Pakistan: A Comparative Analysis". International Journal of Business \& Social Science. Vol. 3 No. 7 , hal 253-257.

Vinnicombe, T. 2010. "AAOIFI reporting standards: Measuring compliance”. Advances in Accounting, incorporating Advances in International Accounting, 26, hal 11-35

Undang-Undang Nomor 21 Tahun 2008 tentang Perbankan Syariah

Yasin, N. 2009. Hukum Ekonomi Islam. UIN Malang Press. Malang. 